THE JOURNAL GASTRONOMY TOURISM

Volume 6 Issue 2, December 2019, 146-161

Tersedia daring di:

https://ejournal.upi.edu/index.php/gastur

Gastronomy Tourism Journal

\title{
Primadeva Utama Catering Makassar's Business Development Strategy
}

\author{
Ghaza Naufal Zhafirin ${ }^{1}$, Gita Siswhara ${ }^{2}$, Bagja Waluya ${ }^{1}$ \\ ${ }^{1}$ Indonesia University of Education, Jl. Dr. Setiabudhi No. 229, Bandung 40154, Indonesia \\ ${ }^{2}$ NHI Tourism Academy, Jl. Raya Lembang KM 12.8, Kabupaten Bandung Barat 40391, \\ Indonesia
}

*Corresponding Author. E-mail: Ghaza24.gg@gmail.com (Ghaza Naufal Zhafirin)

\begin{tabular}{|l} 
ABSTRACT \\
This study aims to determine how the strategy that must be carried out by Primadeva Utama \\
Catering is to develop business in the face of increasingly fierce catering industry competition in \\
the city of Makassar. This research uses quantitative descriptive methods. The data obtained were \\
then analyzed using IFAS matrices, EFAS matrices, IE matrices, SWOT matrices, and QSPM \\
matrices. The IFAS and EFAS matrix analysis results show that the internal factors with the \\
highest value are the taste and portion of food, while for external factors is a broad target market, \\
ranging from the lower middle class to the upper class. Based on the results of the IE matrix \\
analysis, Primadeva Utama Catering is in quadrant five. This position shows a good growth \\
strategy used by the company is concentration through horizontal integrity, which is innovating or \\
modifying products and utilizing economies of scale in profits in production and marketing. With \\
this in mind, the authors recommend 7 alternative strategies for developing the Primadeva Utama \\
Catering business based on the results of the SWOT matrix analysis. Through data processing \\
using QSPM, it can be seen that the alternative is a priority strategy to innovate on a price menu \\
and flexible service package by considering consumer demand trends, these trends are a form of \\
service events and consumer purchasing power with Stas. a value of 7.17. \\
Keywords: Business Development Strategy; SWOT Analysis; QSPM Analysis; Catering \\
Final Proof Received: December 2019 $\quad$ Revised: May 2019 \\
\hline \hline First Received: March 2019
\end{tabular}




\section{Introduction}

Tourism in Indonesia is currently growing in line with economic development. Tourism is the third source of foreign exchange after oil and gas and palm oil. Indonesia is a country that has a variety of cultures, languages, ethnic groups and special foods from various regions. Seeing this diversity, Indonesia can become an attraction for foreign and domestic tourists.

South Sulawesi is one of the provinces in Indonesia with tourism showing a graph that is increasing from year to year. This is in line with government policy so that the world of South Sulawesi tourism is improved and expanded to increase the country's foreign exchange income, expand employment and introduce the native culture of South Sulawesi. Makassar City is the largest city on Sulawesi Island and is the capital of South Sulawesi Province. Makassar City is often one of the tourist destinations, because Makassar City itself has many attractions ranging from natural tourism, educational tourism, culinary tourism, and shopping tourism. Data on the visit of foreign and domestic tourists to Makassar City in 2018 is 5,567. 114 tourists (Central Bureau of Statistics of the City of Makassar Tourism and Culture)

The tourism sector plays an important role in the Indonesian economy. The culinary industry is one part to support the development of the tourism sector. The development of the culinary industry today is not only the fulfillment of basic human needs, but has become a lifestyle among modern society. Therefore we need a strategic role and synergy of all supporting elements of the industry, both in terms of the availability of raw materials, supporting facilities and infrastructure as well as quality workforce (Ningsih. C, 2014)

In this modern era, many people (tourists) deliberately come to tourist destinations just to enjoy regional specialties. Therefore, the culinary industry is now growing rapidly with the consumption patterns (food) of people who think practically so that businesses are interested in building culinary businesses in the form of restaurants, cafes, catering to hawker food. The development of culinary tourism trends has influenced the development of the food industry in Indonesia. Seeing this, the culinary industry is one of the important aspects that can influence the development of the tourism sector.

Catering is part of the culinary industry which is engaged in food service. Catering is a food and beverage service that is equipped with equipment and supplies for the process of making, storing, and serving, to be served at the location desired by the customer. The catering business in the city of Makassar is now mushrooming everywhere. Starting from providing party catering services, office catering, industrial catering, training catering, hospital catering and so on. The following is a comparison of the number of caterers in Makassar City:

Table 1. Data on Number of Caterers by Classification in Makassar City

\begin{tabular}{ccc}
\hline No. & Year & Amount \\
\hline 1 & 2016 & 89 \\
2 & 2017 & 96 \\
3 & 2018 & 110 \\
\hline \multicolumn{2}{l}{ Source: Executive Secretary of DPC APJI Makassar City }
\end{tabular}
(2018)

Based on table 1.2 above, that the number of caterers in the city of Makassar has increased from year to year, in 2018 alone it has been as much as 110 . It is clear that currently the catering business is being favored by business people in Makassar City.

The author chose Primadeva Utama Catering as the object of research, because this caterer has been involved since 1974 in fulfilling customer orders. Based on the information that the author got from Mrs. Irza Masadayeni as the owner of Primadeva Utama Catering, in 2018 last year the number of orders and revenues decreased. The following is the data obtained by the 
author regarding the number of bookings and income at Primadeva Utama Catering that the authors listed from 2016 to 2018 . Details of ordering data for catering services are illustrated in the following table:

Table 2. Data Orders for Primadeva Utama Catering Services 2016-2018

\begin{tabular}{cc}
\hline Year & Order Amount \\
\hline 2016 & 687 \\
2017 & 595 \\
2018 & 442 \\
\hline $\begin{array}{l}\text { Source: } \text { Report of the Finance Primadeva Top Catering } \\
\text { (2018) }\end{array}$
\end{tabular}

Table 2 illustrates that the number of Primary Primadeva Catering orders has declined in the last 3 years. In 2016 Primadeva Utama Catering received 687 orders, while in 2017 Primadeva Utama Catering received as many as 595 orders, which means that Primadeva Utama Catering decreased 92 orders. P No. 2018 Top Primadeva Catering received 442 significant bookings, Primadeva Utama Catering reduced the order of 153 events compared to 2017. Based on data obtained by the author from Mr. Mirza Revelita Primadeva can be concluded that, Top Primadeva Catering refused the number of orders in the last 3 years and the most significant decline occurred in 2018 to reach 153 events.

Decreasing the number of orders certainly has an impact on reducing the amount of turnover obtained by Primadeva Utama Catering. This can be proven with income data which will be illustrated in the following table:

Table 3. Main Catering Turnover Data for 2016-2018

\begin{tabular}{|c|c|}
\hline Year & Turnover \\
\hline 2016 & $6,580,081,500$ \\
\hline 2017 & $5,075,301,050$ \\
\hline 2018 & $3,354,686,000$ \\
\hline
\end{tabular}

Based on Table 3, it is clear that Primadeva Utama Catering has decreased turnover. In 2017 Primadeva Utama Catering experienced a turnover of $\mathrm{Rp}$. $1,504,780,450$ or $22.9 \%$ from the previous year. Whereas in 2018 Primadeva Utama Catering has decreased again by $\mathrm{Rp}$. $1,702,615,050$ or equivalent to $33.9 \%$.

The decline in the number of bookings and revenue of Primadeva Utama Catering in the last 3 years is inseparable from the increasing number of culinary business competition. In recent years more and more have established culinary businesses in the same field, namely catering, so this has become a cause of increasingly intense competition and has influenced the decline in the number of bookings and revenue of Primadeva Utama Catering. Therefore, a strategy is needed in maintaining the Primadeva Utama Catering business so that it can develop better. Meanwhile, before deciding to develop a company, it must consider factors that can later influence the success of the company's own development, both internal and external (Desti Mulyani BR.Purba, 2011). Companies can develop strategies to overcome external threats, seize opportunities and maintain internal strengths and increase internal weaknesses.

Based on the background above, it appears that there is a problem in terms of increasingly fierce competition which affects Primadeva Utama Catering's income. The author will formulate a strategy of what needs to be done by Primadeva Utama Catering to overcome it so that the business can survive and thrive, it is necessary to do research on the company's SWOT analysis. After understanding the problem, the following problem statement is made:

A. What internal factors include the strengths and weaknesses of Primadeva Utama Catering?

b. What external factors include the opportunities and threats of Primadeva Utama Catering?

c. What business strategy should be implemented by Primadeva Utama Catering? 


\section{Literature Review}

\subsection{Definition of Catering Services /} Catering

Catering comes from English catering, which means serving the needs of the party. Based on this meaning, catering is usually intended to provide food at parties, such as weddings, birthdays, or other celebratory parties. Catering is an effort in service in terms of providing / serving food requests, for various purposes (Purwati, 1994).

Catering is a type of place for managing food that cooks different foods in a place that serves food (Moehyi, 1992). Finished food is transported to other places to be served, for example, to parties, meetings, meetings, cafeterias or industrial cafeterias.

The food served can be in the form of snacks and can also be a complete meal for one or more foods, depending on customer demand. Food providers that serve families usually send food using baskets better known as food.

\subsection{Classification of Catering / Catering Services}

The term jasaboga in Permenkes number 1096 of 2011 is defined as a food processing business that is served outside the place of business based on orders made by individuals or business entities. The regulation also categorizes the types of food service industries in Indonesia, divided into 5 big groups based on their service coverage, including:

\section{a. A1 catering services}

Catering services that serve the needs of the general public, with food processing that uses household kitchens and is managed by the family.

b. A2 catering services

Catering services that serve the needs of the general public, with processing that uses household kitchens and employs labor.

c. A3 catering services

Catering services that serve the needs of the general public, with processing that uses specialized kitchens and employs labor. d. Class B catering services

Catering services that cater to the needs of the community specifically for Hajj congregations, transit dormitories, offshore drilling, companies and domestic public transportation with processing that uses special kitchens and employs labor.

e. Class $\mathrm{C}$ catering services

Catering services that serve the needs of international transportation and aircraft with food processing that uses a special kitchen and employs labor.

\subsection{Types of Catering}

Several types of catering are generally divided into the following categories (Fitria \& Kaswara, 2009), namely:

\subsubsection{Catering}

Like a food stall, this catering serves individual requests. Consumers can freely choose the menu presented. Each catering package, usually consists of three to four kinds of home menu that is packaged in a basket or box. Catering catering usually, much ordered at lunch by employees, students or households.

\subsubsection{School Catering}

School catering is intended to meet individual needs. The difference is that the amount served in one food delivery is more than the catering basket. This caterer meets the dining needs of staff and teachers and school students. That way, the school can guarantee that its students get food and drink in accordance with proper nutrition.

The type of food served also avoids artificial ingredients, such as flavoring, coloring, and preservatives. Usually, the school will work together with a special catering. This is done to facilitate control of food quality. In addition, the school does not need to pay a high price.

\subsubsection{Catering Employees}

Catering employees also specifically serve orders for company employees every 
day. Generally, this catering will provide employee lunch packages. The food provided can use order in the form of basket, box or buffet.

The food menu served consists of rice, drinking water, vegetables and side dishes according to company orders. In addition to providing lunch for employees, this type of catering can also serve special occasions, such as the uniqueness and relinquishment of positions, company birthdays and company meetings.

\subsubsection{Wedding Caterers}

Food providers that are generally present in the community are nothing but special caterers that cater to large events, for example weddings, state events, or other parties. Consumers who use this catering service will be facilitated from the various hassles of holding a celebration. They not only sell food, but also provide food preparation services, decorating events and maintaining food service outlets.

Types of food served are generally in the form of a buffet (buffet) with a variety of menus ranging from appetizers (appetizers), core (main dishes), desserts (dessert), to serving snacks or snacks. The price offered varies depending on what package is taken by the consumer.

\subsubsection{Health Caterers}

Catering is not much different from catering a school or office. One thing that distinguishes the intended consumer is the patient from the hospital or those who care about health. Health catering is identical as diet catering. This diet is not always intended for those who want to be thin, but those who are exposed to certain diseases or just want to go on a healthy diet can order food from this diet caterer.

Because it's called health catering, automatically the food offered is not random food. Usually the cooking process requires the presence of a nutritionist, who will calculate the nutritional intake needed by each consumer. The food served will be the ideal nutritional composition. This caterer offers a slightly more expensive price than other caterers, because the cooking process is done one by one, according to the needs of each consumer.

\subsubsection{Outside Catering Service}

Receive food orders where the serving location is different from the kitchen processing location. The location of the presentation usually depends on consumer demand and consumers can ask whether it is equipped with services or not. If it is equipped with a service, the caterer must prepare a presentation and a waiter, while without service, food is only sent to consumers.

\subsection{Strategy Management}

\subsubsection{Definition of Management}

According to Drs. Oey Liang Lee (in Rapanna \& Kanio, 2017) management is the art and science of organizing, organizing, directing and overseeing human resource planning to achieve stated goals. Whereas according to (Yunus, 2016) in his book said management is states consisting of processes that govern, lead, and control the four processes have their respective functions to achieve company goals.

\subsubsection{Types of Strategies}

In principle, strategies can be grouped based on three types of strategies (Rangkuti, 2015), namely:

a. Management Strategy

Management strategies include strategies that can be carried out by management with a macro strategy development orientation. For example, product development strategies, pricing strategies, acquisition strategies, market development strategies, financial strategies and so on.

b. Investment Strategy

This strategy is an investment-oriented activity. For example, whether the company wants to carry out an aggressive growth strategy or try to enter 
market penetration, a survival strategy, a rebuilding strategy for a new division or a divestment strategy and so on.

\section{c. Business strategy}

Business strategy is also often called a functional business strategy because this strategy is oriented to the functions of management activities for example, marketing strategies, production or operational strategies, distribution strategies, organizational strategies and strategies related to finance .

\subsubsection{Strategy Levels}

There are three levels or strategic levels (Rangkuti, 2015) are as follows:

a. Corporate Strategy

According to Andrews (in Rangkuti, 2015), corporate strategy is a strategy that is compiled in a business, when companies will compete by changing distinctive competence into competitive advantage .

Strategies at the corporate level are the foundation and reference for developing strategies at the lower level (business unit strategy and functional strategy).

\section{b. Business Unit Strategy}

Companies that produce various types of products will compete at various levels of business or market. Based on this business strategy is emphasized in Business Unit Strategies, Business Groups Strategic, Business Segments, Natural Business Units or Product Market Units . According to Hall, Abell and Hammond (in Rangkuti, 2015) in principle the Business Unit Strategy has the following characteristics such as, have a mission and strategy, producing products or services related to mission and strategy, produce specific products or services, and compete with competitors that are clearly known

\section{c. Fun Strategy}

The functional strategy drawn refers to all purchasing activities, such as creating a standard pricing strategy based on a certain profit margin percentage for each type of goods purchased. This functional strategy is more operational in nature because it will be directly implemented by management functions that are under its responsibility, such as the production/ operational management function, marketing management function, financial management function and human resource management function.

\subsection{Strategy Management Model}

The strategic management model based on that proposed by Wheelen and Hunger (in Husein Umar, 2010) is as follows:

a. Mission

A company naturally chooses a vision, which is the ideals and founders for future progress. As a step to achieve the vision, it is necessary to have a mission that is steps to achieve the company's vision and implemented by all members of the company.

b. Organization goals

The goals of the organization are part of the mission statement, which is a broad statement of what the company will aim for. c. Organizational Strategy

Each industry has a different strategy from each other, but there are relatively few strategies that can be applied to various forms of industry and company size. These strategies are classified as generic strategies. d. Environment

Understanding the internal and external environmental conditions is very important so that the strategies carried out are consistent and realistic with the situation and conditions.

e. Functional Strategies and Policies

Functional strategy is a guide in carrying out various activities, so it is consistent not only with the main strategy, but also other functional areas strategies.

f. Programs, Budgets and Work

Prosecutors

Good planning that is having the determination to achieve goals, realistic, efficient and reasonable. Planning should be formed in detail and short term, so that planning will be seen. In planning it must 
have a program accompanied by a budget and work procedures.

g. Evaluation and Control

Evaluation and control are intended to better ensure that all activities carried out by the company refer to agreed plans so that there are no deviations and tolerance limits.

\subsection{SWOT Analysis}

\subsubsection{Analysis of the Internal Environment}

All organizations have strengths and weaknesses in their management functions, no company or organization is equally strong in all its functions.

Internal environmental analysis is carried out to determine the level of competitiveness of the company based on the company's internal conditions. The company's internal factors can be fully controlled so that the weaknesses it knows can be corrected. Internal analysis is according to Porter, known as value chain strategies to position the company on the matrix and finding competitive advantage through the company's core competition analysis. This value chain requires that to reach a margin, the company must be supported by main and supporting activities. Internal data can be obtained within the company itself (Rangkuti, 2015), such as:
a. Financial statements (Balance Sheet, Profit and Loss, Cash-flow , Funding Structure)
b. Report on human resource activities (number of employees, education, expertise, experience, salary, turn-over)
c. Report on operational activities
d. Report on marketing activities

\subsubsection{Analysis of the External Environment}

The external environment is all events outside the company that have the potential to influence the company (Jauch \& Glueck, 1994). External data can be obtained from the environment outside the company (Rangkuti, 2015), such as market analysis, competitor analysis, community analysis, supplier analysis, government analysis, and analysis of specific interest groups.

\subsubsection{IFAS Matrix and EFAS Matrix}

According to Reddy Rangkuti (2015) before the strategy is implemented, the strategy planner must have analyzed the external environment to find out the various possible opportunities and threats. Strategic issues to be monitored must be determined because these problems might affect the company in the future. The following are methods for determining the External Strategy Factor:

a. Arrange it in column 1 (5 to 10 opportunities and threats).

b. Give the weight of each factor in column 2, starting from 1.0 (very important) to 0.0 (not important). These factors are likely to have an impact on strategic factors.

c. Calculate the rating (in column 3) for each factor by providing a scale ranging from 4 ( outstanding) to 1 ( poor ) based on the influence of these factors on the condition of the company concerned. Rating the threat rating is the opposite. For example, if the threat value is very large, the rating is 1 . Conversely, if the threat value is slightly rating 4 .

d. Multiply the weights in column 2 by rating in column 3 , to get the weighting factor in column 4 . The result is a weighting score for each factor whose value varies from 4.0 (outstanding) to 1.0 (poor).

e. Use column 5 to comment or note why certain factors were chosen and how the weighting score is calculated.

f. Add up the weighting score (in column 4 ), to get the total weighting score for the company concerned. This total value shows how certain companies react to external strategic factors.

According to Freddy Rangkuti (2015) after the internal strategic factors of a company were identified an IFAS table was compiled to formulate these internal strategic factors within the framework of the company's Strength and Weakness. The stages are as follows:

a. Determine the strengths and 
weaknesses of the company in column 1.

b. Give the weight of each of these factors a scale ranging from 1.0 (most important) to 0.0 (not important), based on the effect of these factors on the company's strategic position. (All of these weights cannot exceed the total score of 1.00).

c. Calculate the rating (in column 3 ) for each factor by providing a scale ranging from 4 ( outstanding) to 1 ( poor), based on the effect of these factors on the condition of the company concerned. Positive variables (all variables included in the strength category) are given values ranging from +1 to +4 (very good) by comparing them with industry averages or with major competitors. While negative variables, the opposite. For example, if a company's weakness is huge compared to the industry average, the value is 1 , whereas if the company's weakness is below the industry average its value is 4 .

d. Multiply the weights in column 2 by rating in column 3 , to get a weighting factor for each factor whose value varies from 4.0 (outstanding) to 1.0 (poor).

e. Use column 5 to comment or note why certain factors were chosen, and how the weighting scor is calculated.

f. Add up the weighting score for the company concerned. This total value shows how a particular company reacts to its internal strategic factors

\subsubsection{IE Matrix}

The IE Matrix can identify 9 cell corporate strategies, but in principle the IE matrix cell counterbalance can be grouped into three main strategies, namely:

a. Growth strategy which is the growth of the company itself (cells 1,2 and 5) or diversification efforts (cells 7 and 8).

b. Stability strategy is a strategy that is implemented without changing the direction of the strategy that has been set.

c. Retrenchment strategy (cells 3,6 and 9) is an effort to reduce or reduce the business done by the company.

\subsubsection{SWOT Matrix}

The SWOT matrix is the stage of finding alternative strategies in developing a business. The SWOT matrix develops four types of strategies (Rangkuti, 2015), namely:

a. SO Strategy

This strategy is made based on the company's way of thinking, namely by utilizing all the power to seize and take advantage of maximum opportunities .

b. ST Strategy

This strategy uses the company's strengths to overcome threats.

c. WO Strategy

This strategy is implemented based on the utilization of existing opportunities by minimizing existing weaknesses.

d. WT Strategy

This strategy is based on activities that are defensive and try to minimize existing weaknesses and avoid threats.

The understanding of the strengths, weaknesses, threats and opportunities in the SWOT matrix are as follows:

a. Strength

Strength is a resource / capability that is controlled or available to a company that makes the company relatively superior compared to its competitors in meeting the needs of the customers it serves. Strength comes from the resources and competencies available to the company.

b. Weakness

Weakness is a limitation / deficiency in one or more resources / capabilities of a company relative to its competitors, which is an obstacle in meeting customer needs effectively.

c. Opportunities

Opportunities are the main favorable situation in a company's environment. The main tendency is one source of opportunity. d. Threat

Threats are the main unfavorable 
situations in a company's environment. Threats are the main obstacle for the company in achieving the desired position.

\subsubsection{QSPM Matrix}

The decision making stage can be carried out using the Quantitative Strategic Matrix (QSPM) matrix , the technique used in stage three (stage 3) of the technical strategy formulation analysis framework, clearly using which alternative strategies are most suitable to be chosen.

\section{Materials and Methods}

\subsection{Jen is Research}

This type of research uses a descriptive quantitative method. The purpose of this descriptive study is to solve systematic and factual problems regarding the facts and characteristics of the population. The quantitative approach will be used to obtain assessments from Primadeva Utama Catering employees and Primadeva Utama Catering consumers on internal and external factors from the Primadeva Utama Catering SWOT analysis. This study is intended to describe the actual situation based on facts or events and existing data, then the data is processed, analyzed and further processed on the basis of theories that are studied and used as discussion material so that ultimately it produces a conclusion that can be used as a basis for providing the best advice for places and managers that are subject to research.

\subsection{Research Objects and Subjects}

The object of research is an important part of a study, which became a focus point of the study. The research object explains about what or who is the object of research. You can also add other things if necessary. The object of research in this study is how to apply good strategies for the development of the Primadeva Utama Catering business.

The research subject was conducted at Primadeva Utama Catering which is located at Jalan Kakatua II No. 116, OUTahan Parang, Mamajang District, Makassar City ,
South Sulawesi. This catering has been established since 1986, it is one of the big caterers in Makassar that is accustomed to serving big events.

The founder of this catering is Mrs. Aszah Wajalla, starting from private capital, this catering initially only served Tumpeng orders but, over time this catering began to develop to be able to serve large events such as weddings, government events, community organizations, large corporate events and etcetera. This company opened a new subsidiary that served in the party and decoration equipment rental in 2013 such as tents, chairs, air conditioners, decorating tools and so on. The company was named Primadeva Eksotika.

The owner of the Primadeva Utama Cateing now is Mrs. Irza Masdayeni who is the biological child of Mrs. Aszah Wajalla, who allowed the author to conduct research there. Researchers chose Primadeva Utama Catering as a research subject because Primadeva Utama Catering is one of the major caterers in the city of Makassar, but the amount of revenue and ordering of Primadeva Utama Catering has fallen in the last 3 years .

\subsection{Data Sources}

The data source of this research comes from the owner of Primadeva Utama Catering, Primadeva Utama Catering's employees, Primadeva Utama Catering's employees and the documentation of data on the statistical agency data, company data and online news portal.

\subsection{Populations and Samples}

The population in this study is the owner of Primadeva Utama Catering, Primadeva Utama Catering employees and Primadeva Utama Catering consumers. The target consumers of Primadeva Utama Catering are the subjects in this study are clients who use the services of Primadeva Utama Catering.

A good sample is a sample that has a population or is representative means that it 
describes the state of the population or reflects the population to the maximum but even if it represents a sample it is not a duplicate of the population. The sample in this study consisted of clients who used the services of Primadeva Utama Catering and were deemed suitable. This study uses the Isac and Michael formula with a population of 442 counted during the 2018 event .

In this study, the authors used the Isac and Michael formula in determining the sample for Primadeva Utama Catering consumers with data on the number of consumers in 2018 being 442 .

Based on the description of the Isac and Michael tables, the number of samples used as respondents in this study is seen from a population of 442 people in 2018 and an error rate of $10 \%$ is 168 people, with the intended respondent being the consumers of Primadeva Utama Catering.

\subsection{Data Collection Techniques}

Data collection techniques used by the authors in this study are as follows:

\subsubsection{Observation}

Observation is a data collection tool that is carried out how to observe and record systematically the symptoms being investigated. The advantages of observational data collection techniques are a direct tool for examining various symptoms. Many aspects of human behavior can only be observed through direct observation and can be noted in a series of symptoms.

\subsubsection{Questionnaire}

Questionnaire method is a list that contains a series of questions about a problem or area to be examined. Researchers will distribute questionnaires to respondents (those who answer so they are investigated) especially in survey research to obtain data. The purpose of this questionnaire or questionnaire is to obtain information relevant to the research objectives and obtain information about a problem simultaneously. The questionnaire submitted must be a valid and reliable questionnaire, so that the results of the questionnaire are accurate.

\subsubsection{Interview}

The question-and-answer process in research that takes place verbally in the name of two or more people face-to-face listening directly to information or information The purpose of the interview itself is to gather information and not to change or influence respondents' opinions. Interviews were conducted with the owner of Primadeva Utama Catering and its employees. The interview is a direct interview.

\subsubsection{Documentation}

Documentation is intended to obtain data directly from the research site, including relevant books, regulations, activity reports, photographs, documentary films, data relevant to research. In this study the authors get data in the form of company sales for the last 3 years, the history of the company's development which is reprocessed by the author and photographs related to the company.

\subsection{Data Analysis}

Data analysis was performed after distributing questionnaires to 168 consumers who use the services of Primadeva Utama Catering, distributing questionnaires to Primadeva Utama Catering employees, interviews with owners and documentation studies. The first analysis uses the IFAS matrix for internal factor analysis, then the EFAS matrix for external factor analysis. Then the results are inputted into the IE matrix to determine the type of strategy and to the SWOT quadrant to determine the nature of the strategy. After that, a SWOT matrix analysis is performed in which the results are inputted to the QSPM matrix to determine priority strategies for Primadeva Utama Catering. 


\section{Results and Discussion}

\subsection{IFAS Matrix}

The results of this study are IFAS matrix with 9 strength factors and 6 weakness factors get a value of 2.53. The details are as follows:

Table 1. Priasva Utama Catering Matrix Analysis

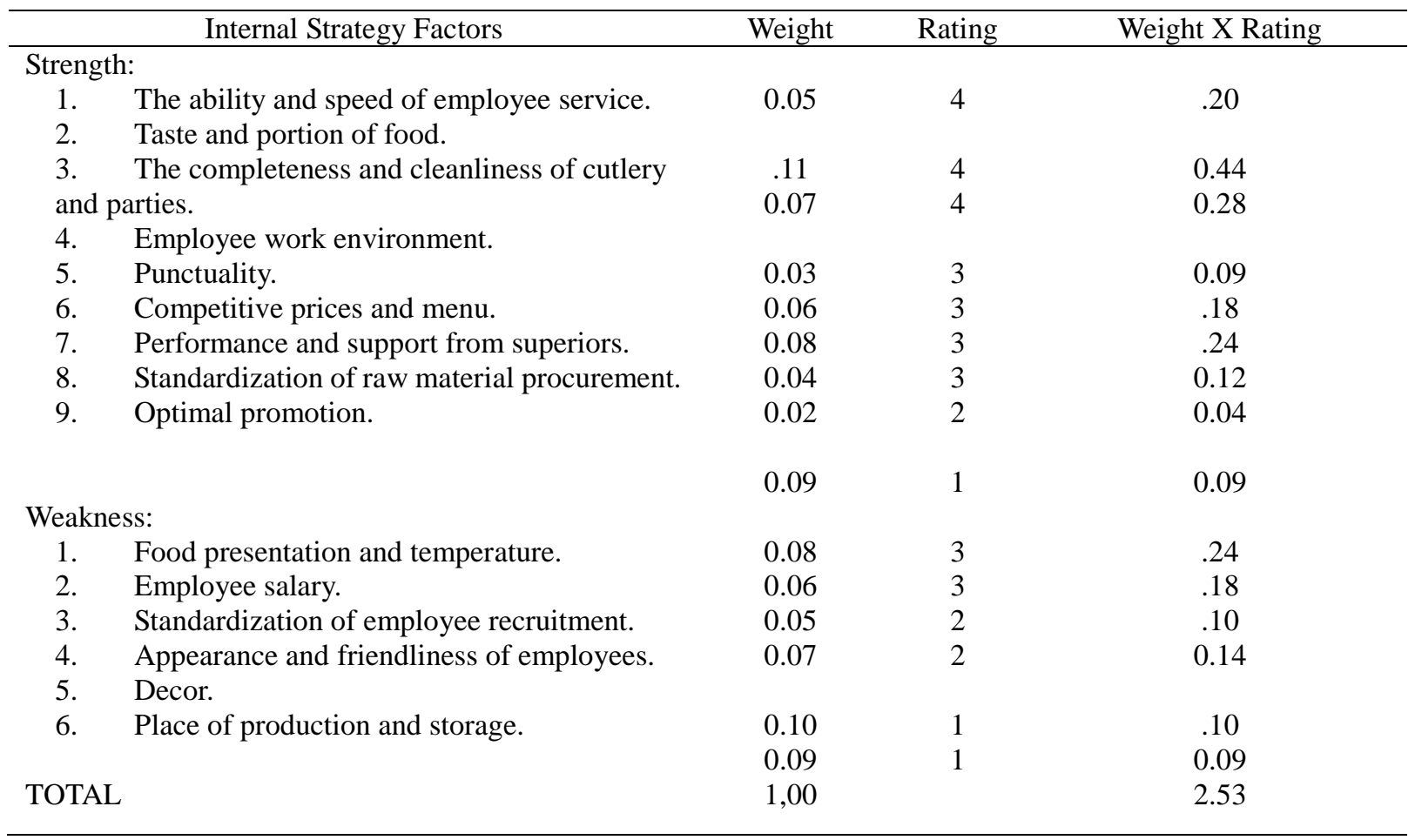

\subsection{EFAS Matrix}

The results of this study are the EFAS matrix with 5 chance factors and 2 threat factors get a value of 2.76. The details are as follows:

Table 2. EFAS Primadeva Utama Catering Matrix Analysis

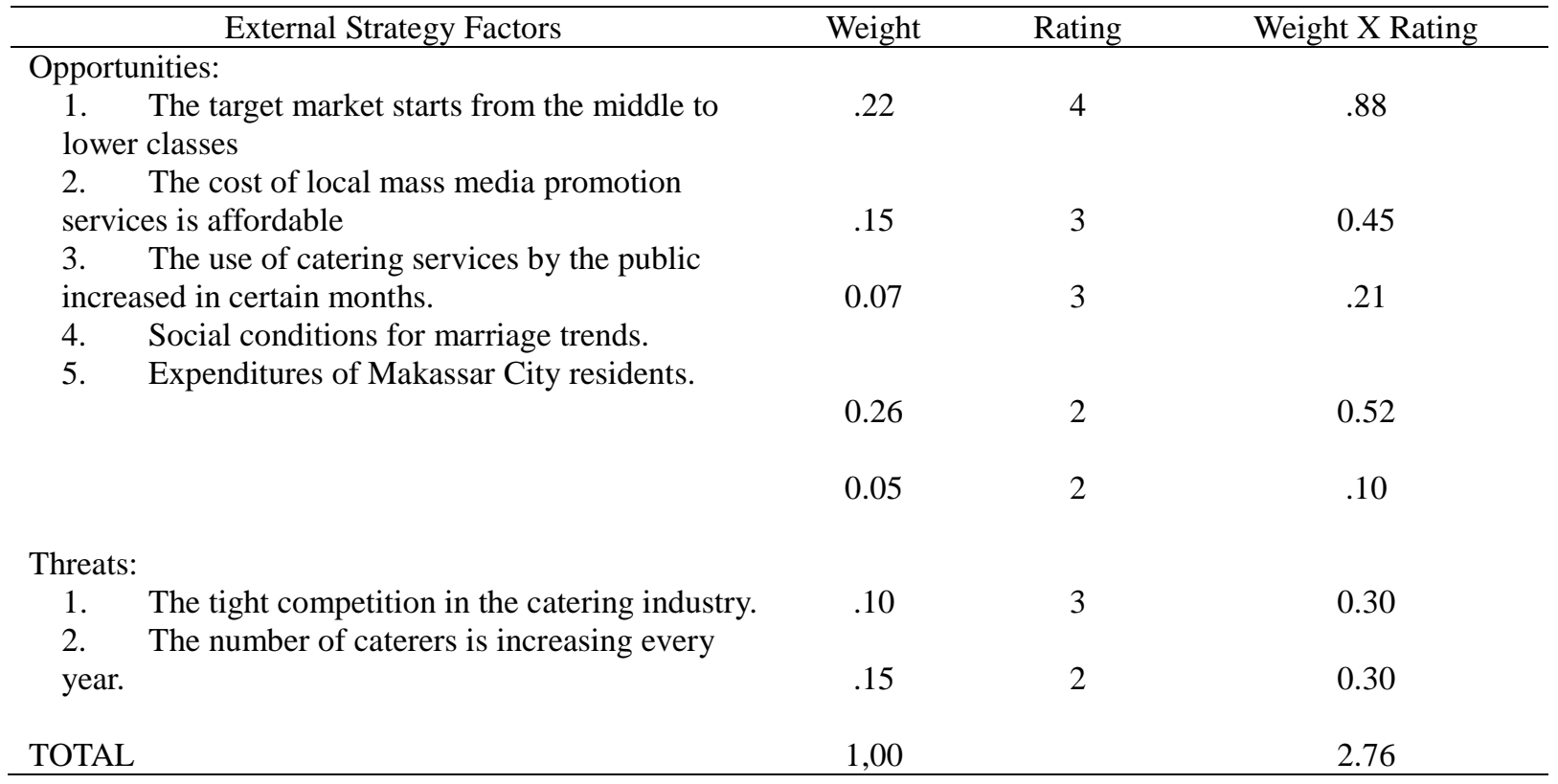




\subsection{IE Matrix}

When entered into the IE matrix, the position of Primadeva Utama Catering is in

cell V with coordinates $(2.53 ; 2.76)$. Here are the results in the IE matrix:

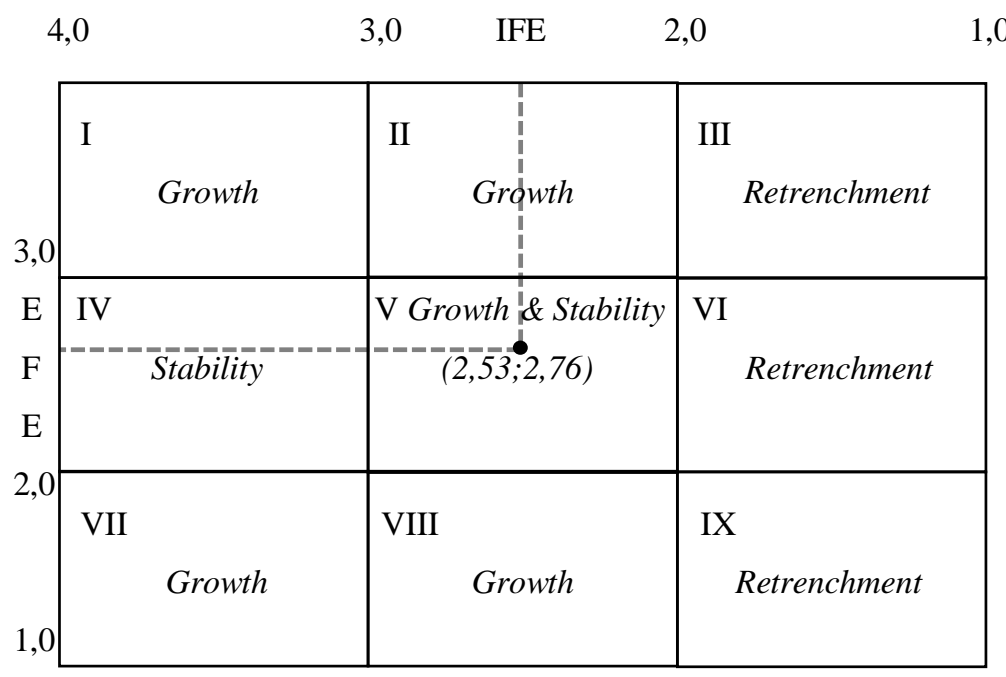

Figure 1. IE Primadeva Main Catering Matrix

$\mathrm{H}$ acyl IE matrix analysis Primadeva position Top Catering is in cell $\mathrm{V}$ ie Growth and Stability . According to Fredy Rangkuti (2015) if the position of the IE matrix analysis is in cell $\mathrm{V}$ then a good growth strategy used is constentation through horizontal integrity.

A growth strategy through horizontal integrity is an activity carried out by the company to expand the company such as building a business in a new location or expanding the company's network through marketing or cooperation. This strategy is also relatively intensive aimed at avoiding loss of sales and loss of profit so it suggests that companies continue to maintain product quality and service quality and the company must also strive to improve the types of products and services, both modifying or renewing.

The business that can be done by Primadeva Utama Catering is to increase sales and profits by utilizing the advantages of economics of scale in both production and marketing. Companies can expand markets, production facilities and technology through development/ refreshment in every internal and external sector through acquisitions or joint ventures with other companies in the same industry. Primadeva Utama Catering can also innovate or modify products or services according to the latest market demand, the aim of which is to increase the sale value

and product quality.

\subsection{SWOT Quadrant Position}

The next step is to enter the sum of the IFAS matrix and EFAS matrix values, into coordinates in the SWOT quadrant. Following is the position of the Primadeva Utama Catering SWOT quadrant:

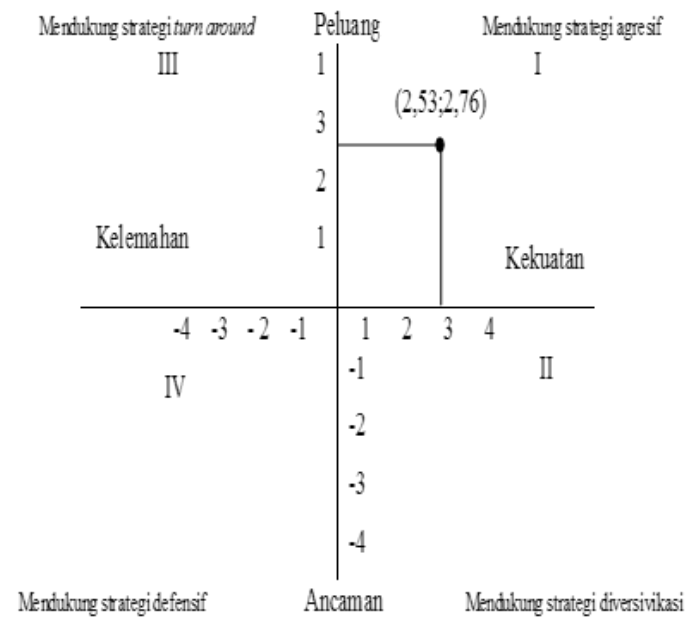

Figure 2. SWOT Quadrant Position 
Quadrant SWOT Position Top Primadeva Catering is in quadrant I with the coordinates of 2,$53 ; 2,76$ which supports an aggressive strategy. This quadrant shows a very favorable situation because the company has opportunities and strengths so that it can take advantage of existing opportunities. The strategy that must be applied to support this condition is an aggressive growth policy (Growth Oriented Strategy).

Primadeva Utama Catering improves technology and human resources in increasing production capacity, for example, expanding promotions through local mass media, social media or other ways of expanding the market, doing cooperation or joint ventures with vendors wedding party activities, and making innovations or modifications to the product or service in order to increase the sale value and quality of the product or service.

\subsection{SWOT Matrix}

Through the SWOT matrix analyst the writer obtained 7 alternative strategies for Primadeva Utama Catering based on the results of the SWOT matrix analysis. The following is an explanation and elaboration of 7 alternative Primadeva Utama Catering strategies:

\subsubsection{SO Strategy}

This strategy is based on the company's way of thinking, namely by using all the company's strengths to take advantage of the Primadeva Utama Catering opportunity.

a. Establish strategies in pricing and innovating package service menus by creating a second brand .

Primadeva Utama Catering created a good strategy in setting prices according to consumers' purchasing power as well as innovating catering service menu menus by creating a second brand . Creating a second brand is useful so that companies continue to earn revenue and not lose revenue, with the second brand the company has a variety of service menus and packages whose market objectives are in accordance with the purchasing power of consumers from the lower classes by utilizing the big names of Primadeva Utama Catering.

b. Expanding promotions by utilizing various media that pay attention to the time, target market and the right form of promotion.

Primadeva Utama Catering can expand marketing through various media such as mass media, social media or other media that support marketing. The company also has to determine the right form and time of promotion so that the promotional objectives can reach the consumers with maximum, useful efforts to maintain the existence of Primadeva Utama Catering.

\subsubsection{ST Strategy}

This strategy was made using the strengths of Primadeva Utama Catering to avoid threats.

a. Maintaining the company's potential advantages that are the hallmark of the company at competitive prices.

This strategy is more intensive where the company still maintains company excellence such as employee service, taste and portion of food, the completeness of tableware and parties as well as competitive prices that are characteristic of Primadeva Utama Catering will provide added value to overcome the competition in the industry. This advantage is not necessarily possessed by every company, so it is big enough for Primadeva Utama Catering to maximize this advantage.

b. Increase production by conducting joint ventures or cooperation to reach the potential of the catering service business.

Primadeva Utama Catering cooperates with useful vendors for the company with the aim of improving the quality of products, adding to the menu of services offered and streamlining the production process. Working closely with vendors makes it easy for Primadeva to meet various kinds of consumer demand. 


\subsubsection{WO Strategy}

This strategy is implemented based on the utilization of existing opportunities, by overcoming the weaknesses that are owned by Primadeva Utama Catering.

a. Increase creativity in product presentation, service and decoration by following the trend in the form of event services according to the target market.

Primadeva Utama Catering makes product presentation standards such as shape, appearance, color and temperature of the product useful for improving product quality. The company also added new forms of decoration that saw the current trends, such as expanding the form of the company into catering \& decoration so that the company would not miss the trend of the times and other similar companies.

b. Improve the quality of human resources by standardizing and educating employees.

Primadeva Utama Catering must make variations in employee recruitment and create training around SOPs to educate employees. This effort is useful to maximize production / operational processes that will affect the quality of products / services.

\subsubsection{WT Strategy}

This strategy is based on activities that are defensive and aimed at minimizing existing weaknesses and avoiding threats.

Standardize all lines of the company's organizational structure to be able to face the fierce competition in the catering industry.

Standardization is carried out by companies in the kitchen operations, building operations, HR recruitment, finance, marketing, customer service, and all company information for employees.

\subsubsection{QSPM Matrix}

This calculation method is carried out after the previous stage is completed and produces alternative strategies. But from the strategies obtained previously, the company must be able to make a selection strategy to adjust to the company's conditions.

Based on the data from the QSPM matrix calculation, it can be seen the priority strategy with the results of the STAS value of 7.17, namely, Establishing strategies in determining prices and innovating service package menus by creating a second brand .

Primadeva Utama Catering created a good strategy in setting prices according to consumers' purchasing power as well as innovating catering service menu menus by creating a second brand . Creating a second brand is useful so that companies continue to earn revenue and not lose revenue, with the second brand the company has a variety of service menus and packages whose market objectives are in accordance with the purchasing power of consumers from the lower classes by utilizing the big names of Primadeva Utama Catering.

\section{Conclusions}

The results of research conducted by the author regarding the Primadeva Utama Catering Makassar Business Development Strategy, can be drawn several conclusions.

The results showed that an internal factor analysis of Primadeva Utama Catering was found. The first factor of strengths or strengths that can be potential and driving the development of catering is the taste and portion of food served, the ability and speed of employee service, the completeness and cleanliness of eating utensils and parties, employee work environment, the role and support of superiors, having standard procurement of raw materials and selective towards suppliers, prices and menu packages that are always updated and competitive, caterers come to the venue on time, promotions are optimal.

Researchers also download emukan results of the analysis of internal factors Primadeva Top Catering form of weakness or weaknesses that need to be repaired or minimized by this company is the appearance and the friendliness of the employees, menu decoration offered, 
presentation and temperature of the food served, the place of production (kitchen) and storage of materials standard, lack of education and skill standards in employee recruitment, employee salaries are not yet satisfactory.

The results of the study also showed that an external factor analysis was found by Primadeva Utama Catering. First, the opportunity or opportunies that can benefit companies to grow is the intended target market area ranging from the middle to the bottom to the top, promotional services in local media with a cost that is affordable enough, spending residents of Makassar, the use of services catering service crowded by the public in the month of Ramdhan and after school holidays, the social conditions of the community towards the marriage trend.

Researchers also found the results of the analysis of the external factors of Primadeva Utama Catering in the form of threats or treatments that must be overcome and avoided by catering. The competition in the Makassar city catering industry is already tight and the number of caterers in the city of Makassar is increasing every year.

These factors make the writer formulate the relevant strategies to be implemented for the development of Primadeva Utama Catering .

The results of IE matrix analysis of the position of Primadeva Utama Catering are in cell $\mathrm{V}$, namely Growth and Stability with coordinates $2.53 ; 2.76$. The strategy used is concentration through horizontal interaction that is utilizing the benefits of economics of scale both in production and marketing, expanding markets, production facilities, utilizing technology, conducting joint ventures or developing products.

Primadeva Utama Catering's alternative alternative strategies based on the results of the QSPM matrix analysis are: Establishing a strategy for pricing and innovating service package menus by creating a second brand .

\section{References}

Central Statistics Agency for Tourism and Culture of Makassar City (2018)

Desti Mulyani BR.Purba. (2011). Comparative Analysis of Stock Prices and Trading Volume of Shares Before and After Stock Split.

Executive Secretary of DPC APJI Makassar City (2018)

Fitria, H., \& Kaswara, RA (2009). Book Smart Business Catering . Jakarta: Transmedia.

Husein Umar. (2010). Marketing and Business Research . Jakarta: Gramedia Main Library.

Jauch, LR, \& Glueck, WF (1994). Management and Strategic Company Policies . Jakarta: Erlangga.

Ningsih, C. (2014). The Synergy of Tourism-Based Creative Industries with the National Industry Development Strategy Towards Globalization. Resort \& Leisure Management .

Ningsih, C., \& Sudono, A. (2016). The competitiveness of Indonesian tourism industry in facing the ASEAN Economic Community (AEC). Heritage, Culture and Society.

Permenkes number 1096 in 2011

Primadeva Utama Catering's Financial Statements (2018)

Purwati, T. (1994). Catering Management . Yogyakarta: FPTK, Teacher Training and Education Institute.

Rangkuti, F. (2015). Techniques for Dissecting Business Case SWOT Analysis . Jakarta: PT. Gramedia Main Library.

Rapanna, P., \& Kanio. (2017). Management Philosophy . Jakarta: Mighty Media Celebes.

Regulation of the Minister of Tourism and Creative Economy (PERMEN PAREKRAF) No.18 of 2014 Article 1 paragraph 2

Suwantoro, G. (2004). Tourism Basics . Yogyakarta: ANDI.

Tourism Act No.10 of 2009 
Turgarini, D. (2016). Introduction Aceh Traditional Culinary as Tourist Attractions.
Yunus, E. (2016). Strategic Management . Yogyakarta: ANDI. 